\title{
Product Purchase Decision Analysis from Bittersweet by Najla Dessert Box
}

\author{
Reni Kusmiati $^{1}$, M. Syamsul Maarif ${ }^{2}$, Suprehatin $^{3}$ \\ ${ }^{1,2}$ School of Business, IPB University, Jl. Raya Padjajaran Bogor, Indonesia \\ ${ }^{3}$ Department of Agribusiness, Faculty of Economics and Management, IPB University, \\ Jl Agatis Kampus IPB Darmaga, Bogor 16880 \\ Corresponding Author: Reni Kusmiati
}

DOI: https://doi.org/10.52403/ijrr.20220149

\begin{abstract}
The development of the food and beverage business sector has great opportunities in Indonesia. Bittersweet by Najla is the pioneer of the first and very famous dessert box in Indonesia. Bittersweet by Najla's ability to see this business opportunity brought the dessert box business to be famous and in demand by consumers. Online sales of Bittersweet by Najla have increased due to the momentum of the Covid-19 outbreak, so Bittersweet by Najla has greatly benefited during the pandemic. This study aims to analyze the factors that influence the decision to purchase dessert box products through brand image. Factors that are thought to influence brand image are the marketing mix and electronic word of mouth (EWOM). The study was conducted on 375 respondents who were selected by volunteer sampling, with criteria over 17 years old, domiciled in Jabodetabek and have purchased a product at least once during the last six months through an online shopping application. Data was collected by distributing online questionnaires. Data were analyzed using descriptive analysis and SEMPLS using the SmartPLS application.

The results showed that the majority of the 375 respondents studied were female by 57.07 percent, dominated by the age of 20 to 30 years (generation Y) at 76.80 percent. The majority of respondents' education level is strata one by 78.40 percent, while in occupations the dominating occupation is 60.53 percent of private employees. Based on the results of the study indicate that the marketing mix affects brand image and purchasing decisions. EWOM also influences brand image and purchasing
\end{abstract}

decisions. In addition, brand image significantly influences purchasing decisions.

The managerial implication that can be implemented is by implementing the STP strategy, which makes it easier for millennial consumers to acquire products and improve services for all online shopping applications by implementing promotions according to the momentum. Implementation of the $4 \mathrm{C}$ marketing mix strategy, increasing the role of EWOM and improving the brand image function.

Keywords: brand image, dessert box, EWOM, marketing mix, purchase decision

\section{INTRODUCTION}

Small and Medium Enterprises (MSMEs) have a large and crucial contribution to the Indonesian economy. MSME is a business that has resistance to crises or economic turmoil. However, with the global Covid-19 pandemic, the impact of the economic crisis is higher than the 1997-1998 crisis. Therefore, digital transformation is one of the right recommendations for MSMEs to survive during the pandemic (Kominfo, 2020).

The development of the food and beverage business sector has great opportunities in Indonesia. This can be seen from the growth trend of the food and beverage industry over the last ten years, which has always been positive (Figure 1). The growth of the food industry is also supported by the contribution of the online 
shopping business in the food or culinary sector in Indonesia, which is increasing rapidly, especially during the Covid-19 pandemic (Food.detik.com 2020). This development makes the internet a good marketing tool for online-based businesses, one approach can be to use marketing through social media. Marketing through social media has been done by various culinary SMEs, including Bittersweet by Najla.

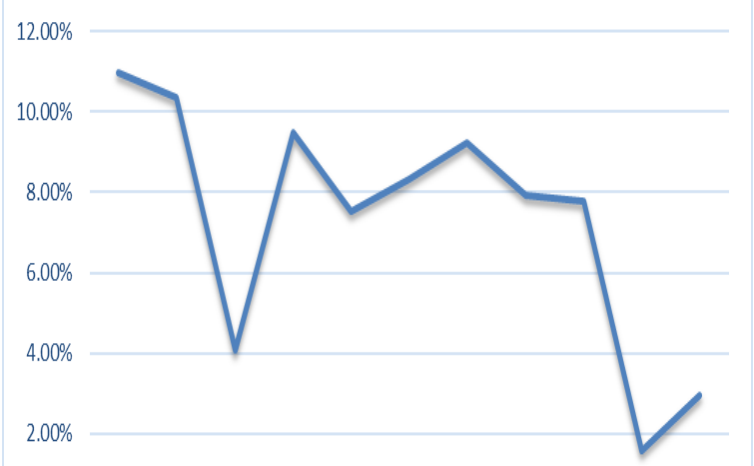

$0.00 \%$

$2011201220132014201520162017201820192020 \quad 2021^{*}$

Source: Research Industry Data 2021

Figure 1: Trends in food and beverage industry growth data for 2011-2021*

Social media is an internet media that is very useful for carrying out promotional activities or broad communication to customers and potential customers (Sumarwan 2018). Social media can function as a medium that shows the company's openness to the wider community as well as a window for the public to find out the company's profile and the products it offers. The high cost of advertising on social media is an important thing that business actors need to consider. Based on research from a study conducted by Elitemarketer.id (2020), that the cost of digital advertising spending in 2016 exceeded the cost of advertising on television and finally in 2020 the cost of digital advertising far exceeded that of TV advertising, meaning there was a significant increase. Overall that advertising on social media reached 15.36 billion US dollars or reached 21 ,

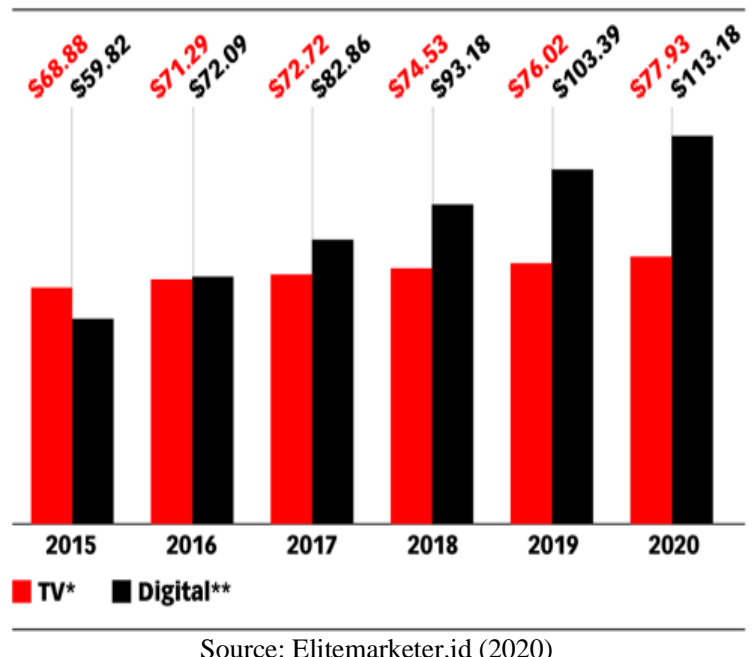

Figure 2: Cost of Digital Advertising vs. TV Advertising in 2015 to 2020

Advertising activities on social media also affect brand image. because with advertising on social media, people will be aware of the presence of a brand (brand). The brand is represented by a certain symbol or quality of the product so that it can compete with competitors with similar products. Customers who are accustomed to using certain brands tend to have consistency in brand image (Andreani et al. 2012). So by remembering the brand of a product will make consumers remember the product. The awareness of this brand is also one of the factors that influence the purchasing decisions of potential consumers.

Bittersweet by Najla is the pioneer of the first and very famous dessert box in Indonesia. Bittersweet by Najla's ability to see this business opportunity brought the dessert box business to be famous and in demand by consumers. This is marked by the increasing number of resellers and the massive advertising of Bittersweet by Najla products on social media. During 2017 until entering 2019, this business is growing rapidly. This is marked by officially opening a cafe in Kalibata as its first outlet and at the same time becoming the Bittersweet by Najla central store to strengthen its business existence. In the course of its fast-growing business, currently Bittersweet by Najla produces 2000-3000 portions per day which are sold 
to resellers and agents in all major cities on the island of Java, several cities in Kalimantan, Sumatra and Makassar (bittersweetbynajla.com 2020).

This online marketing technique is generally dominated by social media and ecommerce whose marketing activities are influenced by the behavior of the buyer. Then this gives rise to a new consumer behavior so that a $4 \mathrm{C}$ marketing mix is needed that focuses on the consumer's perspective. According to research by Hutauruk (2020), consumer behavior is highly prioritized to strengthen the relationship between the influence of the $4 \mathrm{C}$ marketing mix on purchasing decisions. With the $4 \mathrm{C}$ mix, it is a reflection of marketing through social media. The application of the 4C marketing mix (Customer Needs, Customer Convenience, Customer Cost and Customer Communication) is an option in this research because it can be used as an effort by sellers or companies to retain their customers and even acquire new customers.

Consumer purchasing decisions in choosing products online and according to their needs should consider processes that facilitate product acquisition. Javadi et al. (2012) stated that consumers will shop online when they get convenience, product certainty that suits their needs and minimal risk borne by consumers if the product received is not in line with expectations. One of the acquisitions of product-related information can be found through electronic word of mouth (EWOM). EWOM can also be used as a factor that can influence purchasing decisions (Mican and Taut, 2020). Based on these considerations, the marketers see the opportunity for EWOM as one of the cost savings for product promotion which has been a burden on the company's costs. This is also supported by Li et al.

Brand image- It is also used as one of the factors that greatly influence consumers in purchasing a product, especially if the purchase is made online. Soni and Vergeshe (2018) state that brand trust in products is a major factor in determining online purchasing decisions. Because without a well-packaged product form, consumers will not be interested in the product. Therefore, research on the factors that influence product purchase decisions at Bittersweet by Najla is needed to support increased product sales.

The current online sales system contributes greatly to sales revenue compared to offline. Bittersweet by Najla also experienced the same thing that $90 \%$ of its sales came from online sales (bittersweetbynajla.com, 2020). Bittersweet by Najla's online sales have increased due to the momentum of the Covid-19 outbreak, so Bittersweet by Najla has greatly benefited during the pandemic. Changes in shopping patterns by relying on an online system that is easier and more practical. Online shopping can save time to buy products without coming to offline stores (physically existent stores). Although the momentum of the pandemic has caused many changes in shopping services to consumers with an online system, Bittersweet by Najla continues to use offline stores. This opportunity is used to further maximize the existing marketing channels because the existing market share is still small. It aims to focus on consumer needs so that sales revenue will be maximized by utilizing all marketing channels both online and offline.

Based on the phenomena described above, it is interesting to conduct research on what factors influence the purchase decision of the Bittersweet by Najla dessert box product. The number of outlets and resellers of this dessert box pioneer continues to increase from year to year, thus opening up opportunities for increased sales (ijn.co.id, 2020). This study also explores the role of marketing mix, EWOM and brand image on purchasing decisions. In addition, the rapid development of Indonesia's digital economy can be used as a momentum for all online business ventures, especially Bittersweet by Najla to develop their business. Bittersweet by Najla's efforts to increase sales are by synergizing all 
factors that can support consumer purchasing decisions for their products.

The formulation of the problem in this research is as follows:

1. How is the influence of the marketing mix on brand image and purchasing decisions for Bittersweet by Najla dessert box products?

2. How does EWOM affect brand image and purchasing decisions for Bittersweet by Najla dessert box products?

3. How is the influence of brand image on purchasing decisions for Bittersweet by Najla dessert box products?

4. How is the marketing strategy formulation and managerial implications carried out by the Bittersweet by Najla dessert box?

\section{LITERATURE REVIEW \\ Buying decision}

According to Hanaysha (2017), purchasing decisions are a buying decisionmaking process that involves a sequence of choices formed by consumers before making a purchase of the desired product according to their willingness to fulfill their needs. The purchase decision takes into account decisions related to the place of purchase, brand, model, quantity or quantity of the desired purchase, the time required to purchase, the amount of money to be spent and the payment method used in the purchase.

Kotler (2000) states that purchasing decisions are actions of consumers to want to make a purchase or not to a product. Meanwhile, according to Schiffman and Kanuk (2008), the purchase decision (purchase decision) is the selection of the occurrence of two or more alternative choices. In addition, according to Gajjar (2013), suggests that the purchasing decision process can be interpreted in a simple model which includes the input stage, process stage, and output stage. At the input stage (input) consists of various information obtained by consumers about the product purchased, the process stage is how consumers make decisions and the output stage (output) is the result of consumer decision making on the product they buy.

This purchase decision can be influenced by various variables so that it is hoped that this research can provide an additional reference for the company or marketing actors in increasing the sales of their products. One of the approaches to the marketing mix (marketing mix) can be used as one of the variables that influence purchasing decisions.

\section{Marketing Mix}

The marketing mix that is currently being used is the $4 \mathrm{C}$ marketing mix which focuses more on the perspective of the customer (customer), especially in this new normal era, there has been a change in consumer behavior. According to Lauterborn (1990), the 4C marketing mix is a marketing strategy that does not only focus on product marketing and sales but on communication with target customers from beginning to end with the following details:

1. Consumer Needs (Customer Needs)

Consumer needs are solutions that can be met based on the fact that consumers need products more because products can meet consumer needs. Consumers can replace the product used if it is not in accordance with the wishes and needs of consumers. By understanding customers, it will be much easier to create products that are useful for consumers.

2. Consumer Convenience (Customer Convenience)

Consumer convenience is focused on the ease experienced by consumers in using the product or service. Consumers tend to choose products that can facilitate consumers in the process of using the product.

3. Consumer Costs (Customer Costs)

Price is only a small part of the total cost of purchasing a product by the customer. Costs do not only include the price of goods but include the time it takes the customer to get to the location in terms of making a product purchase. Costs can 
also include the benefits or nonusefulness of the product to the customer. Consumers will calculate the costs that will be incurred to get the goods compared to the value obtained in the acquisition of these goods.

4. Consumer Communication (Customer Communication)

Communication has always been the key to marketing because without good communication between the company and consumers, the application of the marketing mix will not necessarily succeed. Communication has a focus on two-way communication and synergizes all the strategies that consumers want for the company. This communication forms the interaction of the customer both before, during the process and even after the product sales process is carried out. Communication is a customeroriented approach to product sales. Therefore, this marketing strategy can be easily implemented through the use of social media.

\section{Electronic Word of Mouth (EWOM)}

Before the development of internetbased communication and information technology, sellers or parties who market products utilize promotional channels through personal word of mouth (WOM) communication. According to Kotler and Keller (2012), word of mouth is a communication process in the form of providing good recommendations made by individuals or groups related to products or services that aim to provide personal information. Along with the development of digital-based information technology and influenced by the dynamic social needs of society as well as the development of various social media, WOM underwent the transformation of EWOM or electronic word of mouth. According to $\mathrm{Li}$ et al. (2016), EWOM is considered as product feedback, reviews, product discussions and some forms of word of mouth that are delivered online and are effective in offsetting consumers' perceived risk of information imbalance. Based on these considerations, EWOM becomes an important source of information in determining consumer purchasing decisions.

The presence of using EWOM cannot be separated from the role of consumers who share reviews of their experiences on social media after using their products or services. Reviews or reviews made by consumers can be in the form of satisfaction or disappointment in using a product or service. According to Cheung and Thadani (2010) that communication through EWOM can take the form of writing comments, opinions and consumer reviews on weblogs, discussion forums, social networking sites or the web, ebulletin board systems and newsgroups.

According to $\mathrm{Ha}$ and Thu (2020), that the term EWOM has also developed into SWOM or social word of mouth because it uses social networking sites to disseminate product information with a focus on four drivers of positive contributions generated by consumers so that they influence purchasing decisions, which include: (1) experience, (2) opinion leadership, (3) self-reflection and (4) need for uniqueness.

The influence of EWOM is very important for purchasing decisions and also the existence of the products being traded. With good reviews, EWOM can affect the brand image of the product being reviewed, even if good and positive reviews are carried out, it will improve the brand image of the product.

\section{Brand Image}

According to Kotler (2008), brand image is a name, symbol, term, design or synergy of all of them which aims to identify the goods or services of a seller or group of sellers and to make them look different from those of competitors. This is also in accordance with what was stated by Venessa and Arifin (2017) that brand image is an association or belief contained in the minds of consumers which is used as a differentiator from other product brands in 
terms of symbols, letter designs and special colors. Brand image supported by these three components (company image, consumer image and product image) has a positive influence on the structure of purchasing decision making.

The placement of a very strong and positive brand image will make it easier for consumers to remember the product so that it will provide benefits for the company in increasing its sales revenue. This is also supported by Gul et al. (2018), that brands can guarantee the quality of products that will be used by consumers and become a determining factor for the company's success in getting customers.

\section{METHODS}

This research design uses quantitative and qualitative approaches. The quantitative approach is carried out with an online survey of respondents. The qualitative approach was carried out using focus group discussions (FGD) and in-depth interviews. The location of data collection for this research was conducted in Jabodetabek. The location of the research was determined intentionally by considering that Bittersweet by Najla is one of the MSMEs engaged in the culinary business sector related to the pioneer of the first dessert box product in Indonesia. The time of data collection was carried out from March to April 2021 and the implementation of focus group discussions (FGD) and in-depth interviews in October 2021.

The sampling technique used is nonprobability sampling. The non-probability sampling technique used for sampling through questionnaires is a convenience sampling technique. This technique is chosen by selecting consumers who are considered the easiest to provide the information needed and are willing to fill out a questionnaire. Determination of respondents, namely respondents who have purchased a dessert box product Bittersweet by Najla at least in the last month with a minimum age of 17 years. Respondents who are considered are respondents who are adults and are able to think rationally and are able to answer questions from researchers.

Determination of the number of respondents taken in this study followed the rule of thumb Hair et al. (2010) which states that the number of samples required for each parameter estimate of exogenous and endogenous variables is five to 10 observations. The number of question indicators in this study is 40 . Based on these standards, the minimum number of samples for this study is 200 respondents and the maximum sample is 400 respondents.

The sampling technique was through focus group discussions (FGD) and in-depth interviews using purposive techniques (done intentionally). The FGD was conducted with 6 resource persons or experts who understand purchasing decisions and Bittersweet by Najla customers. The FGD was carried out twice at different times due to time constraints and the conditions were still pandemic. Respondents for in-depth interviews were selected with a sampling technique using purposive sampling. The respondents who were interviewed were the Founder of Bittersweet by Najla and the Digital Marketing Expert. Respondents were chosen because they are owners who know the company directly and are practitioners who understand the development of online SMEs.

Data collection through questionnaires using google forms will be distributed to respondents via WhatsApp Groups and social media owned by researchers and related research networks. Then specifically, it will give direct messages to followers of social media accounts who comment on Instagram Bittersweet by Najla. In addition, the questionnaire will be distributed through ads (ads) on Facebook groups and google.

In this study, the FGD was attended by 6 participants or experts from external parties consisting of 2 owners of online culinary SMEs, 1 academician, 2 culinary critics or food bloggers, 1 dessert box 
product consumer. Meanwhile, in-depth interviews were conducted with 2 resource persons, namely the Founder of Bittersweet by Najla and the Digital Marketing Expert. This in-depth interview was conducted by means of online communication to enrich and confirm the research results.

The measurement scale used is the Likert scale. The Likert scale is used for a question that has several answer choices related to agreement. The order used is 1-5 with a value of 1 (strongly disagree), 2 (disagree), 3 (moderately agree), 4 (agree) and 5 (strongly agree).

This study uses two analytical tools, namely descriptive analysis, Structural Equation Model - Partial Least Square (SEM-PLS). The available data will be collected in the form of Microsoft Excel and further analyzed using the Smart PLS application. Based on the background, theoretical basis and framework of thought that has been presented, the authors of this study develop several factors that can influence consumer purchasing decisions for products. The hypotheses in this study are:

H1: Marketing mix has a significant effect on brand image

$\mathrm{H} 2$ : The marketing mix has a significant effect on purchasing decisions

H3: EWOM has a significant effect on brand image

H4: EWOM has a significant effect on purchasing decisions

H5: Brand image has a significant effect on purchasing decisions

The SEM hybrid model is the overall model in the research including the structural model and the measurement model. This SEM hybrid model can be seen in Figure 3.

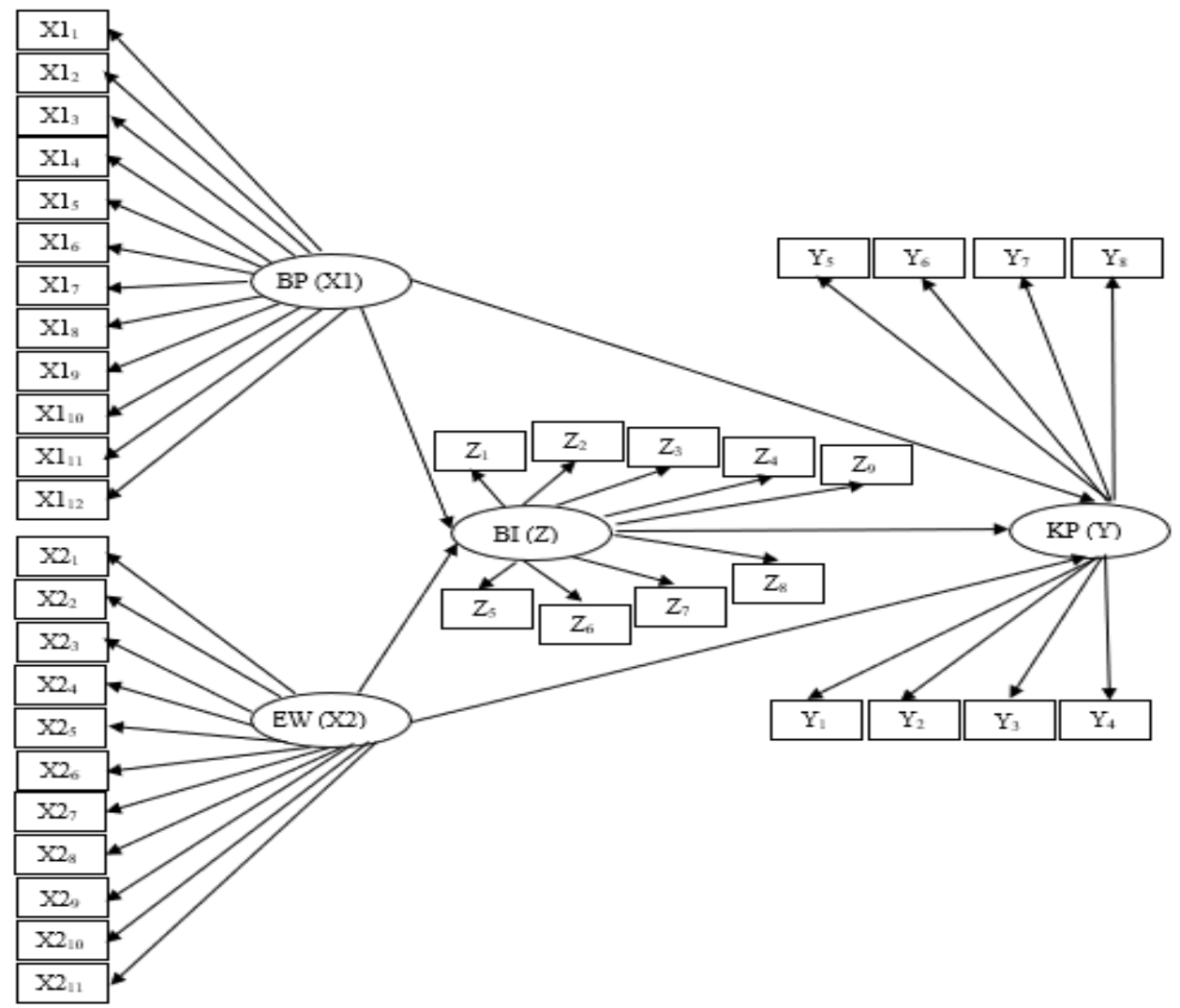

Figure 3: Hybrid SEM Model

\section{RESULT}

\section{Characteristics of Respondents}

The number of respondents in this study were 375 consumers who had bought dessert box products at Bittersweet by Najla at least in the last 6 months with a minimum age of 17 years who have online shopping applications and are domiciled in Greater 
Jakarta. In Table 1, the demographic characteristics of the research respondents are presented. The demographic questions given are gender, age, education, occupation, individual monthly income and expenses, number of family members and domicile.

Table 1: Demographic characteristics of respondents

\begin{tabular}{|c|c|c|}
\hline Characteristics & Total (n) & Percentage (\%) \\
\hline \multicolumn{3}{|l|}{ Gender } \\
\hline - Man & 161 & 42.93 \\
\hline - Woman & 214 & 57.07 \\
\hline \multicolumn{3}{|l|}{ Marital status } \\
\hline - $\quad$ Not married yet & 178 & 47.47 \\
\hline - $\quad$ Married & 197 & 52.53 \\
\hline \multicolumn{3}{|l|}{ Age } \\
\hline - $\quad<20$ years & 3 & 0.80 \\
\hline - $\quad 20-30$ years old & 288 & 76,80 \\
\hline $31-40$ years old & 84 & 22.40 \\
\hline - $\quad 41-60$ years old & 0 & 0.00 \\
\hline \multicolumn{3}{|l|}{ Education } \\
\hline - $\quad$ junior high school & 0 & 0.00 \\
\hline - $\quad$ senior High School & 1 & 0.27 \\
\hline - 3-year diploma & 63 & 16.80 \\
\hline Undergraduate & 294 & 78,40 \\
\hline Level 2 & 17 & 4.53 \\
\hline - $\quad$ Level 3 & 0 & 0.00 \\
\hline \multicolumn{3}{|l|}{ Work } \\
\hline - $\quad$ Student/ Student & 4 & 1.07 \\
\hline - $\quad$ Housewife & 33 & 8.80 \\
\hline - $\quad$ ASN/TNI/Polri & 67 & 17.87 \\
\hline - $\quad$ Laborer & 0 & 0.00 \\
\hline Private employees & 227 & 60.53 \\
\hline - $\quad$ Professional & 2 & 0.53 \\
\hline - $\quad$ Businessman & 40 & 10.67 \\
\hline - $\quad$ Other & 2 & 0.53 \\
\hline \multicolumn{3}{|l|}{ Individual Income per month } \\
\hline - $\quad<$ Rp. $1,000,000$ & 0 & 0.00 \\
\hline - $\quad$ Rp. 1.000 .000 - Rp. $2,999,999$ & 6 & 1.60 \\
\hline - $\quad$ Rp. $3,000,000$ - Rp. $4,999,999$ & 291 & 77.60 \\
\hline - $\quad$ Rp. $5,000,000$ - Rp. $6,999,999$ & 44 & 11.73 \\
\hline - $\quad$ Rp. $7,000,000$ - Rp. 8,999,999 & 13 & 3.47 \\
\hline
\end{tabular}

Table 5.1 Demographic characteristics of respondents (continued)

\begin{tabular}{|l|l|l|}
\hline Characteristics & Total (n) & Percentage (\%) \\
\hline
\end{tabular}

\begin{tabular}{|c|c|c|}
\hline Rp. $9,000,000-$ Rp. $10,000,000$ & 4 & 1.07 \\
\hline > Rp. $10,000,000$ & 17 & 4.53 \\
\hline \multicolumn{3}{|l|}{ Individual Expenses per month } \\
\hline$<$ Rp. $1,000,000$ & 1 & 0.27 \\
\hline Rp. $1.000 .000-$ Rp. $2,999,999$ & 11 & 2.93 \\
\hline Rp. 3,000,000 - Rp. 4,999,999 & 294 & 78,40 \\
\hline Rp. 5,000,000 - Rp. 6,999,999 & 43 & 11.47 \\
\hline Rp. 7,000,000-Rp. 8,999,999 & 14 & 3.73 \\
\hline Rp. $9,000,000-$ Rp. $10,000,000$ & 1 & 0.27 \\
\hline$>$ Rp. $10,000,000$ & 11 & 2.93 \\
\hline \multicolumn{3}{|c|}{ Number of Family Members (one place of residence) } \\
\hline 1 person & 6 & 1.60 \\
\hline $2-3$ people & 216 & 57.60 \\
\hline 4-5 people & 143 & 38.13 \\
\hline$>6$ people & 10 & 2.67 \\
\hline \multicolumn{3}{|l|}{ Domicile } \\
\hline Jakarta & 84 & 22.40 \\
\hline Bogor & 50 & 13.33 \\
\hline Depok & 76 & 20.27 \\
\hline Tangerang & 94 & 25.07 \\
\hline Bekasi & 71 & 18.93 \\
\hline
\end{tabular}




\section{Gender, Age and Status}

The gender of dessert box consumers is dominated by women, as many as 214 respondents, amounting to 57.07 percent. The age of the respondents is dominated by the group aged 20 to 30 years, which is 76.80 percent. According to Sumarwan (2015), gender is very important to determine product or brand positioning. Age is also very crucial to understand what consumers want. The marital status of the majority of dessert box consumers are married $(52.53 \%)$. This group is a new type of family or those who still have small children with a husband and wife who work, so the positioning of the company is very appropriate.

The age grouping of the respondents is limited from the age of 17 years with the assumption that the research respondents are mature and independent to make purchasing decisions. Dessert box consumers who became respondents in this study were more than half dominated by the age of 20 to 30 years, as many as 288 respondents (76.80\%), which means they are included in generation Y (years of birth 1977-1995). Generation $\mathrm{Y}$ is a generation that has been accustomed to technology compared to the previous generation because it was born in the era of information technology development (Oktariani 2016). Therefore, based on Valentine et al. (2013), most of the $Y$ generation are included in the experiencers category because they are action-oriented, follow fashion and have typical media usage habits.

\section{Level of education}

The education level of the respondents in this study was divided into two categories. The first category is respondents with middle and high school education. The second category is respondents with higher education starting from diploma three to three degrees. The majority of the respondents in this study as many as 294 respondents $(78.40 \%)$ were strata one. The second position of the respondent's education is diploma three then strata two. The level of education affects consumers in determining the choice of goods or services used so that they can influence consumers in making purchase decisions.

\section{Work}

The occupations of the respondents are divided into seven groups, namely students, housewives, State Civil Apparatus/ TNI/POLRI, laborers, private employees, professionals, and entrepreneurs. Based on the results of the research that the highest percentage of jobs sequentially are private employees (60.53\%), State Civil Apparatus/ TNI/POLRI (17.87\%), entrepreneurs $(10.67 \%)$, housewives $(8.80 \%)$, students $(1.07 \%)$, professionals $(0.53 \%)$ and others. The type of work affects the social status of consumers. In addition, it will also affect behavior in buying or using products or services.

\section{Income and expenditure}

Information on income and expenditure is needed to determine the level of economy or consumer purchasing power. This will lead to product positioning. Based on the results of the study, the majority of respondents were in the income range of $\mathrm{Rp}$. $3,000,000$ to Rp. 4,999,999 which is 77.60 percent with the most expenses with the same value, namely income $(78.40 \%)$.

\section{Number of Family Members}

Information on the number of family members (who live in the same place) is needed to determine the economic level and purchasing power of consumers. This will affect the consumption pattern of the product to be purchased (Nababan 2013). Based on the results of the study, the majority of respondents have family members (who live in the same place) as many as 2-3 as much as 57.60 percent.

\section{Domicile}

Respondents in this study were spread across Jabodetabek. The results showed that 25.07 percent of the respondents were domiciled in Tangerang. The second position is occupied by DKI 
Jakarta at 22.40 percent and followed by Depok at 20.27 percent. Respondents who live in Bekasi have a percentage of 18.93 percent. Finally, 13.33 percent of respondents live in Bogor.

\section{Purchase Behavior}

In buying a dessert box product at Bittersweet by Najla, a respondent will go through a purchasing decision process. This causes the respondent's buying behavior. Questions about purchasing behavior in the questionnaire included purchase frequency, average purchase per month, the most widely used online shopping application and online purchases of food and other agricultural products (Table 2).

Table 2: Respondent's buying behavior

\begin{tabular}{|c|c|c|}
\hline Purchase Behavior & Total (n) & Percentage $(\%)$ \\
\hline \multicolumn{3}{|l|}{ Purchase frequency } \\
\hline - $\quad$ Every day & 91 & 24.27 \\
\hline $2-4$ times a week & 24 & 6.40 \\
\hline $5-7$ times a week & 16 & 4.27 \\
\hline 1 time a week & 58 & 15.47 \\
\hline 2-3 times a month & 26 & 6.93 \\
\hline 1 time a month & 127 & 33.87 \\
\hline 1 time in 2 months & 17 & 4.53 \\
\hline - $\quad 1$ time in $>2$ months & 16 & 4.27 \\
\hline \multicolumn{3}{|l|}{ Average purchases per month } \\
\hline - $\quad<$ IDR 100,000 & 30 & 8.00 \\
\hline $100,000-350,000$ & 328 & 87.47 \\
\hline $350,000-700,000$ & 17 & 4.53 \\
\hline • $\quad>700,000$ & 0 & 0.00 \\
\hline \multicolumn{3}{|l|}{ The online shopping application used } \\
\hline - Gofood & 159 & 42.40 \\
\hline Grabfood & 83 & 22.13 \\
\hline - $\quad$ Shopee & 61 & 16.27 \\
\hline Tokopedia & 68 & 18,13 \\
\hline - $\quad$ Other & 4 & 1.07 \\
\hline \multicolumn{3}{|l|}{ Purchase of food and agricultural products online } \\
\hline - $\quad$ Yes & 365 & 97.33 \\
\hline - $\quad$ Not & 10 & 2.67 \\
\hline \multicolumn{3}{|c|}{$\begin{array}{l}\text { Types of food and agricultural products that are usually purchased online } \\
\text { (Respondent who answered: Yes) }\end{array}$} \\
\hline - $\quad$ Fruit & 46 & 12.60 \\
\hline Fruits, vegetables, fresh meat, processed food, frozen food & 1 & 0.27 \\
\hline Fresh meat (such as meat: chicken, beef, lamb, etc.) & 37 & 10,14 \\
\hline - $\quad$ Frozen food & 91 & 24.93 \\
\hline - $\quad$ Processed foods (such as meatballs, sausages, nuggets, etc.) & 108 & 29.59 \\
\hline - $\quad$ Fish or seafood products & 39 & 10.68 \\
\hline - $\quad$ Vegetables & 41 & 11.23 \\
\hline - $\quad$ All of the options listed above & 2 & 0.55 \\
\hline
\end{tabular}

\section{Purchase Frequency, average purchase}

The frequency of online purchases in the last six months is divided into eight groups (according to Table 2). The results showed that the frequency of purchasing a product that was most often done occurred to 127 consumers once a month, which was 33.87 percent. The average purchase ranges from Rp. 100,000 to Rp. 350,000, which is 87.47 percent.

\section{Online Shopping App}

The choice of using an online purchase application is very important for consumers in supporting the purchasing decision process. There are many online shopping platforms that can be used to make online purchases, such as food delivery service applications and e-commerce. They are grouped into 5 choices in using shopping applications, namely Gofood, Grabfood, Tokopedia, Shopee and others.

The results showed that the online purchase application used by respondents to buy dessert boxes was dominated by Gofood at 42.40 percent. This is because Gofood always provides promos in the form of product price discounts that can be adjusted to the purchasing power of consumers. 


\section{Most Frequently Purchased Products}

In addition to buying dessert box products online, as many as 365 respondents $(97.33 \%)$ in this study used online shopping applications to purchase food and other agricultural products. The results showed that the types of food and agricultural products purchased by consumers were the majority in the processed food category $(29.59 \%)$ and frozen food $(24.93 \%)$. This is used as an alternative choice by consumers because of the ease of making purchases without having to leave the house so they don't spend a long time buying a product.

\section{Variable Indicator Description}

A description of the indicators for each variable is needed to make it easier to analyze quantitatively and to make it easier to draw conclusions. The results of the answers from respondents were grouped into three, namely (1) strongly disagree and (2) disagree as disagree, (4) agree and (5) strongly agree as agree, while (3) quite agree remained as moderately agree. .

\section{Marketing Mix}

Marketing mix in this research is a marketing strategy used by sellers that is focused on the customer perspective so it is known as the 4C marketing mix (customer, convenience, cost, communication). The marketing mix variable consists of twelve indicators that are measured related to the 4C marketing mix components when buying dessert box products at Bittersweet by Najla. The percentage distribution of the marketing mix variable indicators is listed in Appendix 4. The results showed that as many as 93.60 percent of respondents stated that the Bittersweet by Najla dessert box had a very unique product. This generally means that the marketing mix applied by the seller is very supportive and liked by consumers, namely the uniqueness of the products offered will increasingly make consumers curious and want to buy their products.

\section{EWOM}

EWOM is a means for customers to disseminate information related to products that have been purchased through various social networking sites. The EWOM variable consists of eleven indicators related to the drivers of positive consumer contributions which include experience, opinion leadership, self-reflection and the need for uniqueness. These four motivations will be used by respondents when they are going to buy a Bittersweet by Najla dessert box. The percentage distribution of EWOM indicators is presented in Appendix 5.

The results showed that 89.87 percent of respondents said they would share various information after using the product and they would see reviews from various users before making a purchase. This shows that respondents/consumers who purchase dessert boxes at Bittersweet by Najla have the motivation to share information related to the products purchased and share their experiences.

\section{Brand Image}

Brand image is a belief in the minds of consumers that is used as a differentiator from other brands in terms of the hull, font design and special colors. The brand image variable consists of nine indicators that are measured related to company image, consumer image and product image when buying a Bittersweet by Najla dessert box product. The percentage distribution of brand image variable indicators is presented in Appendix 6. The results showed that as many as 94.40 percent of respondents stated that Bittersweet by Najla was very good. This generally means that the brand image of a product given or offered by the seller will affect consumer purchases because of the consideration of the seller's very good reputation (personal branding).

\section{Buying decision}

Purchasing decision is a person's attitude to buy or use a product in the form of goods or services that are believed to satisfy him/herself and the willingness to bear the risks that may arise. The purchase 
decision variable is determined by the input, process and exit stages. The percentage distribution of purchasing decision indicators is presented in Appendix 7. The results show that as many as 94.40 percent of respondents use online shopping to find the desired product information. In addition, as many as 92.53 percent of respondents seek information on social media for the products they want to buy. Meanwhile, 90.13 percent of respondents look for a lot of positive comments related to products on social media. This is done by respondents to obtain alternative information before making a purchase.

\section{Results of SEM-PLS . Analysis}

In the PLS SEM method that has been carried out, the results of the initial PLS SEM model based on the evaluation of the Outer Model Measurement have been fulfilled. This is based on the results of the convergent validity test, the resulting model shows that all indicators are valid because they have a correlation value above 0.5 (Appendix 10).

Based on the results of the discriminant validity test, the indicators used to measure all variables were valid because they had a value of more than 0.5 . It can be concluded that the variables and indicators used in this study have met discriminant validity. The results of the AVE root and the correlation of latent variables, as well as the results of cross loading are presented in Table 3.

Table 3: Discriminant validity test results

\begin{tabular}{|l|c|c|c|c|c|}
\hline Latent Variable & $\begin{array}{c}\text { Average Variance } \\
\text { Extracted (AVE) }\end{array}$ & Marketing Mix & Brand Image & EWOM & Buying decision \\
\hline Marketing Mix & 0.409 & 0.640 & & & \\
\hline EWOM & 0.462 & 0.781 & 0.680 & & \\
\hline Brand Image & 0.522 & 0.733 & 0.816 & 0.723 & \\
\hline Buying decision & 0.427 & 0.748 & 0.784 & 0.721 & 0.653 \\
\hline
\end{tabular}

Based on the validity test, the parameters used to assess reliability are Cronbach alpha and composite reliability. Table 5.4 shows that the variables used in this study have a Cronbachs alpha value of more than 0.6 and a composite reliability value of more than 0.7 so it can be concluded that the variables used in this study are reliable. The results of Cronbach alpha and composite reliability are presented in Table 4.

Table 4: Cronbach Alpha and Composite Reliability Values \begin{tabular}{|c|c|c|}
\hline Latent Variable & Cronbach's Alpha & Composite Reliability \\
\hline
\end{tabular}

\begin{tabular}{|l|c|c|}
\hline Marketing Mix & 0.868 & 0.892 \\
\hline Brand Image & 0.853 & 0.885 \\
\hline EWOM & 0.907 & 0.923 \\
\hline Buying decision & 0.807 & 0.856
\end{tabular}

After passing the validity and reliability tests, then the evaluation of the inner model is carried out. The parameters used to evaluate the inner model in SmartPLS are the determinant coefficient (R2 Test) and the path coefficient or t-value. The value of $\mathrm{R} 2$ is used to measure the level of variation of changes in the independent variable to the dependent variable. The value of $\mathrm{R} 2$ on the brand images variable is 0.736 and the value of the purchasing decision variable is 0.667 (Table 5).

\begin{tabular}{|l|c|c|}
\multicolumn{1}{|c|}{ Table 5: Value of R square } \\
\begin{tabular}{|l|c|c|}
\hline Latent Variable & R Square & R Square Adjusted \\
\hline Brand Image & 0.738 & 0.736 \\
\hline Buying decision & 0.670 & 0.667 \\
\hline
\end{tabular}
\end{tabular}

The value of $\mathrm{R} 2$ is used to calculate Goodness of Fit (GOF), because in smart PLS there is no special menu to calculate GOF. GOF value is used to indicate whether a model is fit. GOF reflects how much the dependent variable $(\mathrm{Y})$ can be explained by the independent variable (X). Goodness of Fit (GOF) in this study can be measured by the following calculations:

$$
\begin{aligned}
Q^{2} & =1-\left(1-R_{1}^{2}\right)\left(1-R_{2}^{2}\right) \\
& =1-(1-0.736)(1-0.667)=0.912
\end{aligned}
$$

Based on these calculations, the resulting Q2 value of 0.912 . This means that the independent variable $(\mathrm{X})$ which consists of marketing mix, EWOM and brand images can explain 91.2 percent of purchasing decisions and the remaining 18.8 
percent is explained by other variables not included in the model. Thus, it can be concluded that this research model is good to be used as a research model because the Q2 value is more than 80 percent. Because the higher the Q2 value, the better the prediction model of the proposed research model.

\section{Contribution of Indicators to Variables}

The contribution of indicators is needed to explain the dominant influence of each indicator of the research variables that have been determined.

\section{Contribution of Indicators to Marketing Mix Variables}

The latent variable of the marketing mix has twelve indicators that contribute the highest and lowest values. The loading factor value based on this indicator is detailed in Table 6.

Table 6: Value of marketing mix indicator loading factor

\begin{tabular}{|l|l|c|}
\hline Symbol & \multicolumn{1}{|c|}{ Indicator } & Loading factor \\
\hline BP1 & Products as needed & 0.606 \\
\hline BP2 & Products favored by consumers & 0.630 \\
\hline BP3 & Very unique product & 0.701 \\
\hline BP4 & Ease of buying products through online applications & 0.570 \\
\hline BP5 & Ease of product payment with an online system & 0.564 \\
\hline BP6 & Branches of business that reach consumers & 0.659 \\
\hline BP7 & The price of the product is according to the taste & 0.645 \\
\hline BP8 & The price of the product is in accordance with the quality & 0.612 \\
\hline BP9 & Shopping online can save costs & 0.630 \\
\hline BP10 & Good two-way communication media & 0.708 \\
\hline BP11 & Product information via social media & 0.632 \\
\hline BP12 & Product discount information through online shopping application advertisements & 0.699 \\
\hline
\end{tabular}

Based on the results of SEM calculations, the indicators that have the largest contribution are good two-way communication media (BP10) with a loading factor value of 0.708 and a very unique product (BP3) with a loading factor value of 0.701 . This shows that the BP10 indicator is one of the dominant indicators in supporting the implementation of the marketing mix. With the existence of a good two-way communication medium (BP10) in the form of implementing certain events, the company can build good communication and involve its customers in the product sales process. Thus, consumers and potential consumers can easily communicate and obtain information related to the products to be purchased.

The BP3 attribute (very unique product) is also a dominant factor to support the implementation of the company's marketing mix. This unique dessert box product packaging makes consumers curious to buy it. So that the existence of the product can be used as an attraction for consumers. It is proven that the respondents are the majority of the millennial generation who are well-known as a generation that really likes products with unique designs.

\section{Contribution of Indicators to EWOM Variables}

The EWOM latent variable has eleven indicators that contribute the highest and lowest values. The loading factor value based on this indicator is detailed in Table 7.

Based on the results of SEM calculations, the indicator that has the largest contribution is sales service information on social media (EW5) with a loading factor value of 0.794 and product quality is always shared through social media (EW4) with a loading factor value of 0.788. This shows that the EW5 indicator is an indicator that contributes dominantly to EWOM activity. The activity of sharing sales service information on social media (EW5) by consumers can be a factor in the emergence of EWOM. Thus consumers have the motivation to share information related to product sales services through interaction with fellow users on social 
media. The contribution of the EW5 indicator is useful as feedback or input for companies because of the leadership role of consumer opinion in social media.

Table 7: The loading factor value of the EWOM indicator

\begin{tabular}{|l|l|c|}
\hline Symbol & \multicolumn{1}{|c|}{ Indicator } & Loading factor \\
\hline EW1 & Sharing information after using the product & 0.602 \\
\hline EW2 & Reviews from various users of the product & 0.603 \\
\hline EW3 & Memorable experience when buying the product & 0.626 \\
\hline EW4 & Product quality is always shared via social media & 0.788 \\
\hline EW5 & Sales service information on social media & 0.794 \\
\hline EW6 & Dissemination of product information through friends and followers & 0.779 \\
\hline EW7 & Share product information with others & 0.779 \\
\hline EW8 & Likes to provide positive information regarding products & 0.697 \\
\hline EW9 & Likes to give negative information about products & 0.720 \\
\hline EW10 & Posting products on social media as proof & 0.760 \\
\hline EW11 & Posting product info as a form of personal expression & 0.762 \\
\hline
\end{tabular}

The EW4 attribute (product quality is always shared on social media) is also a determining factor for the emergence of EWOM activities. Talking about product quality is very important for consumers before making a purchase. In fact, the EW4 indicator will be even more influential if it is carried out by consumers who have important roles in society, such as the role of figures or influencers who can contribute to forming opinions that will be followed by their followers.

\section{Contribution of Indicators to Brand Image Variables}

The latent variable brand image has nine indicators that contribute the highest and lowest values. The loading factor value of each brand image indicator is listed in Table 8.

Table 8: Value of loading factor indicator Brand Image

\begin{tabular}{|l|l|l|}
\hline Symbol & \multicolumn{1}{|c|}{ Indicator } & Loading factor \\
\hline BI1 & Bittersweet by Najla as a pioneer of dessert boxes in Indonesia & 0.646 \\
\hline BI2 & Bittersweet by Najla's reputation is excellent & 0.647 \\
\hline BI3 & Bittersweet by Najla service is very good & 0.613 \\
\hline BI4 & Shop for Bittersweet by Najla dessert box products according to consumers' lifestyles & 0.765 \\
\hline BI5 & Shopping for Bittersweet by Najla products has a good impression & 0.679 \\
\hline BI6 & Always shop at Bittersweet by Najla & 0.729 \\
\hline BI7 & Bittersweet product packaging by Najla is very attractive & 0.629 \\
\hline BI8 & Very useful product & 0.742 \\
\hline BI9 & Premium quality products & 0.649 \\
\hline
\end{tabular}

Based on the results of SEM calculations, the indicator that has the largest contribution is shopping for dessert box products Bittersweet by Najla according to consumer lifestyle (BI4) with a loading factor value of 0.765 . This shows that the BI4 indicator is an indicator that contributes dominantly to brand image. Shopping for dessert box products in accordance with the consumer's lifestyle (BI4) is a matter of pride for consumers belonging to the millennial generation with an age range of 20-30 years. This means that the brand image of the product will be better by following the current consumer lifestyle so that it will make the product brand more sought after and liked by consumers.

\section{Contribution of Indicators to Purchase Decision Variables}

The latent variable for purchasing decisions has eight indicators that contribute to the highest and lowest values. The loading factor value of each purchasing decision indicator is listed in Table 9.

Based on the results of SEM calculations, the indicator that has the largest contribution is that it has many variations of sales services compared to other brands (KP5) with a loading factor value of 0.741 . This shows that the KP5 indicator is an indicator that contributes dominantly to purchasing decisions. Having a large variety of sales services compared to other brands (KP5) is an indicator that consumers really need to support the 
purchasing decision process. This means that consumer purchasing decisions for products are strongly influenced by the many alternative choices of sales services provided by the seller, so that they do not only rely on one sales channel, but consumers can purchase products not only through offline stores, but also through offline stores.

Table 9: The value of the loading factor indicator of Purchase Decision
\begin{tabular}{|l|l|l|}
\hline Symbol & \multicolumn{1}{|c|}{ Indicator } & Loading factor \\
\hline KP1 & Looking for information on social media before buying & 0.658 \\
\hline KP2 & Looking for information on online shopping before buying & 0.564 \\
\hline KP3 & Product recommended by friends, family & 0.634 \\
\hline KP4 & Lots of positive comments regarding the product on social media & 0.647 \\
\hline KP5 & Has a large variety of sales services compared to other brands & 0.741 \\
\hline KP6 & Product selection based on the number of positive comments & 0.608 \\
\hline KP7 & Purchase products in the near future & 0.673 \\
\hline KP8 & The product will be recommended to others & 0.686 \\
\hline
\end{tabular}

\section{Hypothesis test}

Based on the empirical study model that has been proposed in this study, the next step is to test the hypothesis by testing the path coefficients and t-count on the structural equation model.The path coefficient is a coefficient that indicates the level of significance in hypothesis testing. The hypothesis used in this study is a onetailed hypothesis. The hypothesis is accepted if it has a t-count value of more than 1.96 .

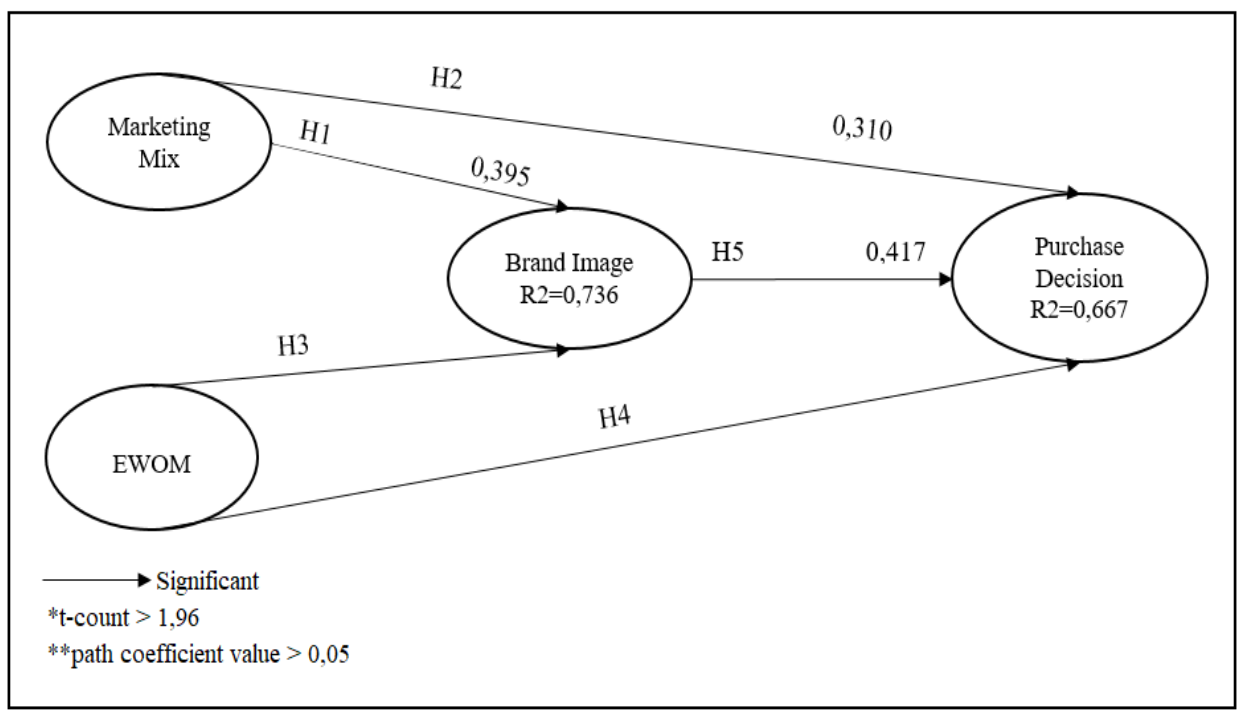

Figure 4: Path diagram of the full model of the processed results

If the path coefficient value is more than 0.05 with a t-count value of more than 1.96 then the influence between variables is included in the significant category. On the other hand, if the path coefficient value is less than 0.05 with a $t$-count value less than 1.96, it is included in the insignificant category (Table 10).

Table 10: Results of path coefficients and t-test of direct influence between latent variables

\begin{tabular}{|l|c|c|c|c|}
\hline \multicolumn{1}{|c|}{ Track } & Path Coefficient & t-count & Conclusion & Description \\
\hline Marketing Mix -> Brand Image & 0.395 & 6,547 & Significant & Accepted H1 \\
\hline Marketing Mix -> Purchase Decision & 0.310 & 6.315 & Significant & Accepted H2 \\
\hline EWOM -> Brand Image & 0.526 & 8,540 & Significant & Accepted H3 \\
\hline EWOM -> Purchase Decision & 0.153 & 2,084 & Significant & Accepted H4 \\
\hline Brand Image -> Purchase Decision & 0.417 & 5.894 & Significant & Accepted H5 \\
\hline
\end{tabular}


The results of hypothesis testing explain that the relationship between variables has a significant direct effect, namely the influence of marketing mix (BP) and EWOM (EW) on brand image (BI). Furthermore, the influence of marketing mix (BP) and EWOM (EW) on purchasing decisions (KP). In the path coefficient, all effects are positive, meaning that the better the marketing mix, EWOM and brand image, the consumers tend to make purchasing decisions.

In addition to having a direct influence, this research also has an indirect effect. This indirect influence includes the marketing mix (BP) which affects purchasing decisions (KP) through brand image (BI) and EWOM (EW) which affects purchasing decisions (KP) through brand image (BI). Table 11 shows the indirect effect between variables in this study.

Table 11: Results of path coefficients and t-test of indirect effect between latent variables

\begin{tabular}{|c|c|c|c|}
\hline Track & Path Coefficient & t-count & Conclusion \\
\hline Marketing Mix -> Brand Image -> Purchase Decision & 0.165 & 4094 & Significant \\
\hline EWOM -> Brand Image -> Purchase Decision & 0.219 & 5.050 & Significant \\
\hline
\end{tabular}

\section{- Effect of Marketing Mix on Brand Image}

Testing the effect, the result is that the coefficient value of the marketing mix path on brand image is 0.395 with a t-count value of 6.547 which means more than 1.96. This can explain that the marketing mix variable has a positive and significant influence on brand image. There are twelve indicators that make up the marketing mix variable. One of them has a strong contribution to describe the marketing mix variables, namely the statement that twoway communication media is good (BP10) with a loading factor value of 0.708 and a tcount of 26.537. This means that the existence of positive marketing mix activities involving good two-way communication media will facilitate the implementation of the marketing mix strategy.

Based on statistics, it means that every 1 percent increase in marketing mix activity will increase brand image by 39.5 percent. The better the company in implementing its marketing mix, the better the brand image of the product.

This finding is in line with the conditions in the field, namely the company has carried out several program activities or events to support the good two-way communication media. The event aims to involve consumers, namely: providing online cake-making courses and webinars related to product image enhancement.

The analysis of these results is also supported by research conducted by Hadi et al. (2015) which states that the marketing mix has a significant influence on brand image which focuses on services for participants of the Royal English course and training institution in Malang. However, according to Seong and Kim (2018), it is explained that the application of the marketing mix will be more effective by adding an element of consumer love for the brand, so that it will increase the chances of consumer purchasing decisions. In contrast, according to research conducted by Kurniawan (2016) that all marketing mix variables have a contribution in influencing brand image. Based on this research, it means that the better the marketing mix that is supported by effective two-way communication media, the higher the brand image known by consumers to the brand. Thus, the first hypothesis (H1) is proven and accepted in this study.

\section{- Effect of Marketing Mix on Purchase Decision}

Testing the effect shows that the value of the marketing mix path coefficient on purchasing decisions is 0.310 with a $\mathrm{t}$ count value of 6.315 which means more than 1.96. The results of this test can explain that the marketing mix variable has a 
positive and significant influence on purchasing decisions. This is indicated by the path coefficient value which is positive. That is, an increase in the marketing mix of sellers will have a direct impact on increasing consumers in determining purchasing decisions.

Based on statistics, it is explained that every 1 percent increase in the marketing mix will increase purchasing decisions by 31 percent. The influence between these variables is significant so that this variable becomes important to consider in supporting purchasing decisions. A positive marketing mix will encourage consumer purchasing decisions, especially if the seller provides an effective two-way communication medium. This will support consumer needs when searching for information related to all products to be purchased. This finding is in line with the conditions in the field, where the seller regularly holds casual chats directly through Instagram (ig live) together with followers who are also consumers. In the online conversation, the seller provides product promotion information in various sales services (such as: online shopping applications, Gofood and Grabfood). This was responded positively by consumers through the comments column of the seller's Instagram account, thus encouraging consumers to immediately decide to purchase.

The results of this analysis are supported by previous research conducted by Astuti et al. (2021) show that the marketing mix has a significant effect on purchasing decisions for consumers of mozzarella cheese. However, the same thing was not stated by Al Rasyid et al. (2017) which explains that the marketing mix does not have a positive effect on purchasing decisions. This is because consumer knowledge regarding products is still low and producers have not optimally marketed their products.

On the other hand, the same research was also stated by the research of Yusmarni et al. (2020) that all marketing mix variables are stated to influence consumer decisions in buying a product. This means that the better the marketing mix formed by good communication media, the higher the consumer's tendency to make purchasing decisions. Thus, the second hypothesis $(\mathrm{H} 2)$ is proven and accepted in this study.

\section{- Effect of EWOM on Brand Images}

Testing the effect shows that the coefficient value of the EWOM path to brand image is 0.526 with a t-count value of 8.540 which means more than 1.96. This can explain that the EWOM variable has a positive and significant influence on brand image. There are eleven indicators that make up the EWOM variable. One of them that has a strong contribution to describe the EWOM variable is the statement that sharing sales service information on social media (EW5) with a loading factor value of 0.794 and a t-count of 30.060 . This means that the existence of positive EWOM activities by involving consumers in sharing product sales service information on social media will make the role of EWOM increasingly needed.

Based on statistics, it is explained that every 1 percent increase in EWOM will increase brand image by 52.6 percent. The better the EWOM activities carried out by consumers, the more likely it is to increase the brand image of the product. Consumers will pay attention to the brand image of the product to be purchased through reviews of other customers who consume the same product and also through the image of the producer or seller. If this is considered good and in accordance with customer expectations, then their trust in the brand produced by the seller will increase. This finding is in accordance with what is happening in the field, namely the company has used influencers who have a positive image to conduct product reviews. This action was chosen by the company because the influencer contributed positively in improving the product's brand image.

This analysis is also supported by previous research conducted by Jalilvand and Samiei (2012) which states that EWOM 
is one of the most effective factors in influencing brand image. With the positive role of EWOM will be able to improve brand image and reduce promotional costs. This is also evidenced by the research conducted by Farzin and Fattahi (2018) indicating that EWOM has a significant influence in the formation of brand image in the minds of consumers. Thus, the third hypothesis (H3) is proven and accepted in this study.

\section{- Effect of EWOM on Purchase Decision}

Testing the effect shows that the value of the EWOM path coefficient on purchasing decisions is 0.153 with a $\mathrm{t}$-count value of 2.084 which means more than 1.96. The results of this test can explain that the EWOM variable has a positive and significant influence on purchasing decisions. This is indicated by the path coefficient value which is positive. That is, the increase in EWOM will have a direct impact on increasing consumers in determining purchasing decisions.

Based on statistics, it is explained that every 1 percent increase in EWOM activities will increase purchasing decisions by 15.3 percent. The influence between these variables is significant so that this variable can be considered as a consumer reference in determining purchasing decisions. Positive EWOM activity will encourage consumers to buy the product, especially if there is a positive consumer opinion regarding product sales service information. This will further convince consumers in deciding to purchase the product.

This finding is in line with the conditions in the field, namely the company has carried out several program activities or events to support the good two-way communication media. The event aims to involve consumers, namely: providing online cake-making courses, direct casual chats via Instagram (ig live) and webinars.

The results of this analysis are supported by previous research conducted by Dhiza et al. (2020) shows that EWOM has a positive and significant effect on purchasing decisions for cafe customers, especially on intensity, content and consumer comments through Instagram. This is also stated by the research of Fan and Miao (2012) that EWOM related to positive consumer reviews significantly affects consumers' purchase intentions for a product. In addition, according to research by El-Seidi and El-Baz (2016) that EWOM not only has a positive and significant impact on consumer buying interest, but greatly affects brand image and brand attitudes. Thus, the fourth hypothesis (H4) is proven and accepted in this study.

\section{- The Effect of Brand Images on Purchase Decisions}

The results of the influence test show that the path coefficient value of brand images on purchasing decisions is 0.417 with a t-count value of 5.894 which means more than 1.96. This can explain that the brand image variable has a positive and significant influence on purchasing decisions. There are nine indicators that make up the brand image variable. One indicator that has a strong contribution to describe the brand image variable is the statement of shopping for dessert box products according to the consumer's lifestyle (BI4) with a loading factor value of 0.765 and a t-count of 29.523. This means that the presence of a positive brand image is obtained from the contribution of the image of consumers who like shopping for dessert box products because they are in accordance with the consumer's lifestyle.

This finding is in line with the facts on the ground, that dessert box products are favored by the millennial generation. Based on the majority of respondents in this study, millennials have a practical, simple lifestyle and are always happy to share their activities on social media. Therefore, the dessert box is one solution for the needs of millennial consumers who want to consume products in a practical and unique way. So that consumers voluntarily share their 
experiences on social media when buying dessert box products because these activities are part of the consumer's lifestyle.

Based on statistics, it is explained that every 1 percent increase in brand image will increase purchasing decisions by 41.7 percent. The influence between these variables is significant so that this variable becomes important to consider in improving purchasing decisions. Brand image has an important role to create trust in the minds of consumers, so that sellers do not only focus on building product and company images but also attach importance to building consumer images. Therefore, the company seeks to improve its image by synergizing the corporate image, consumer image and product image through improving product quality.

This analysis is also supported by previous research conducted by Cahyani and Sutrasmawati (2015) proving that brand image and brand awareness have a simultaneous and significant positive influence on purchasing decisions, meaning that the better the brand image, the higher the purchasing decisions made by Honda motorcycle consumers. Beats. Furthermore, the results of research by Sanjiwani and Atmosphere (2019) that brand image has a significant effect on purchasing decisions. In addition, according to the research of Nurhasanah et al. (2017) that purchasing decisions can also be significantly and positively influenced by consumer trust in brands (brand trust). Thus, the fifth hypothesis (H5) is proven and accepted in this study.

\section{- Indirect Effects Between Variables}

Indirect effect or indirect effect occurs if between two variables there is no direct arrow between the two variables. As for this research model, there are two variables that have an indirect relationship, namely (1) the influence of the marketing mix on purchasing decisions through brand image and (2) the influence of EWOM on purchasing decisions through brand image.
Variables that have a significant influence based on indirect effects with a tcount value of more than 1.96. The first variable that gives an indirect effect between these variables is the influence of the marketing mix on purchasing decisions through brand images. This variable has a path coefficient value of 0.165 and a t-count of 4.094, so it is declared significant.

This finding is in accordance with the conditions in the field that the company's marketing mix is focused on consumers by holding events. Through the role of corporate events, it can be used as a means of communication between sellers and consumers so as to improve brand image. With the increase in the brand image of the product, it will make consumers curious and interested in the products offered so as to improve purchasing decisions. In addition, this field condition is supported by research conducted by Yusmarni et al. (2020) that the performance of the marketing mix formed from the components of price, place and promotion will be able to influence consumer purchasing decisions. Therefore, before making a purchase, consumers will take into account.

The next variable is the influence of EWOM on purchasing decisions through brand image, has a path coefficient value of 0.219 and a t-count of 5.050 so that it is declared significant. This EWOM variable also gives the highest contribution related to the indirect effect on purchasing decisions. Based on the results of the SEM process, it is in accordance with the conditions in the field that EWOM through the role of consumers who like to share information on good product sales services on social media can increase product brand images. With the increase in brand image due to the role of information from fellow consumers, it will encourage consumers and potential consumers to tend to make purchases.

\section{DISCUSSION}

Based on the results of processing and analyzing the data that has been carried 
out in this study, various findings and facts that occurred in the field were obtained and were supported by the results of the FGD and in-depth interviews. There are several managerial implications that will be useful for Bittersweet by Najla in an effort to increase sales, one of which is by implementing the STP (segmenting, targeting, positioning) strategy, which makes it easier for consumers (especially millennials) to acquire products and improve services to all online shopping applications by implementing promotions. according to the momentum. Examples include: providing promo prices for customers who are having birthdays, product bundling, promotions are carried out on employee paydays. STP strategy implementation can involve consumers or followers in every process of the company's business growth. This is done by providing story telling that can touch the emotional connection of consumers when they see the marketing of the product.

The application of the $4 \mathrm{C}$ marketing mix strategy can be used to increase consumer interest in buying, namely by increasing consumer awareness that the products offered can meet consumer needs, such as the need for self-appreciation (selfreward). In addition, to immediately open branches in areas where there is no representative outlet, such as Tangerang and Bekasi. This is very necessary so that the burden of shipping costs for consumers in the area can be minimized. The next recommendation, companies are advised to hold free shipping promos in all online shopping purchasing applications to save on consumer purchasing costs. In order for this communication strategy to be more effective and have a good impact on increasing sales, the role of information related to product discounts in online shopping applications should be improved, especially the provision of discounts to consumers who have made frequent purchases. It aims to retain customers and can add new customers.
The next recommendation for increasing the role of EWOM is that companies can increase EWOM activities with the help of food bloggers to increase consumer awareness of the products offered in order to accelerate brand image improvement. Meanwhile, improving the brand image function does not only focus on the role of influencers or endorsements. However, including the role of a food blogger account to accelerate the increase in brand image. In addition, sellers must also understand the customer journey as a consumer journey when interacting with brands. This is very much needed by potential consumers before finally deciding to buy the product. With a good customer journey, potential consumers will prefer our products over competitors, so that they can improve product brand image and sales opportunities.

\section{CONCLUSION}

The results of the research show that the marketing mix had a positive and significant influence on brand image and consumer purchasing decisions in buying dessert box products. EWOM also has a positive and significant influence on brand image and consumer purchasing decisions. In addition, brand image has a positive and significant influence on consumer purchasing decisions.

The managerial implication that can be implemented is by implementing the STP strategy, which makes it easier for millennial consumers to acquire products and improve services for all online shopping applications by implementing promotions according to the momentum. Implementation of the $4 \mathrm{C}$ marketing mix strategy, increasing the role of EWOM and improving the brand image function. Things that are appropriate and can be applied well to Bittersweet by Najla are dessert box products that have met the needs and desires of consumers, the convenience of the payment system when consumers make online purchases, prices that are comparable to the delicious taste. In addition, there are 
several things that still need to be improved by the company in order to improve purchasing decisions. The first thing is consumer awareness to share product information with others after using the product. The second improvement step is to add outlets in the Tangerang and Bekasi areas to save on shipping costs. Then involve the role of food bloggers to accelerate the improvement of brand image. Another improvement is to study and understand the customer journey that will be carried out by potential customers.

\section{Acknowledgement: None}

\section{Conflict of Interest: None}

\section{Source of Funding: None}

\section{REFERENCES}

1. Al Rasyid M. Harun, Yuliati Lilik N, Maulana Agus. 2017. Analysis of Lifestyle, Innovation, Product and Marketing Mix of Product Purchase Decision Hen's Instant Omelette (Case study in PT Eco Nature Multiindo). Independent Journal of Management and Production. 8(2):519-535.

2. Ardana YA, Rastini NM. 2018. The influence of brand image mediates the effect of EWOM on the purchase intention of Samsung Smartphones in Denpasar City. EJournal of Unud Management. 7(11): 59015929.

3. Astuti R, Deoranto P, Wicaksono MLA, Nazzal A. 2021. Green Marketing Mix: an example of its influence on purchasing decisions. International Conference on Green Agro-Industry and Bioeconomy. IOP Publishing Ltd: 1-9. DOI: 10.1088/17551315/733/1/012064.

4. Bittersweetbynajla. 2020. Bittersweet Success Story by Najla, Pioneer of Dessert Box in Indonesia. [Accessed January 08, 2020]. Available on: https://www.bittersweetbynajla.com/news/6 498

5. Cahyani KI, Sustrasmawati RE. 2015. The effect of brand awareness and brand image on purchasing decisions. Management Analysis Journal. 5(4): 281-288.

6. Cheung MK and Thadani DR. 2010. The effectiveness of electronic word of mouth communication: a literature analysis. BLED proceedings. 2010 June 20; Bled, Slovenia: , Association for Information System Electronic Libraries (AISeL).

7. Dhiza A, Zulkarnain, Widyatsari A. 2020. Effect of Electronic Word of Mouth via Instagram on Purchase Decisions at Cafes in Pekanbaru City. Journal of Economics. 7(1): 15-31.

8. El-Seidi RI, El-Baz D. 2016. Electronic word of mouth effects on consumer's brand attitudes, brand image and purchase intention: an empirical study in Egypt. The Business and Management Review. 7(5): 514-523.

9. Elite marketer. 2020. Info: The Cost of Advertising on Social-Media has Exceeded Television. [Internet]. [Accessed on: November 22, 2020]. Available at: https://elitemarketer.id/news/info-harga-adsuntuk-bisnis/

10. Farzin M, Fattahi M. 2018. eWOM through social networking sites and impact on purchase intention and brand image in Iran. Journal of Advances in Management Research. 15(2): 161-183.

11. Fan WY, Miao YF. 2012. Effect of Electronic Word of Mouth on Consumer Purchase Intention: The Perspective of Gender Diffrences. International Electronic of Business Management. 10(3): 175-181.

12. Food.seconds. 2020. Online Culinary Business: Online SME Food Product Sales Increase during the Corona Pandemic. [Accessed January 08, 2020]. Available on:https://food.detik.com/info-kuliner/d5073186/penjualan-produk-food-ukmonline-meningkat-selama-pandemi-corona.

13. Gajjar NB. 2013. Consumer Behavior and the Process of Purchase Decision. International Journal for Research in Management and Pharmacy. 2(3):8-13.

14. Gul MS, Jan FA, Baloch QB, Jan MF. 2018. Brand Image and Brand Loyalty. Abasyn Journal of Social Science. 3(1):55-74.

15. Ha Le Thi T and Thu VT. 2020. Motivation of guests contributing sWOM on social media: a case in Vietnam. Journal of Asian Business and Economic Studies. Emerald Publishing Limited. 27(1): 1-17. DOI: 10.1108/JABES-05-2020-0055.

16. Hadi DL, Kumadji S, Yulianto E. 202015. The Influence of Service Marketing (Service Marketing Mix) on Brand Image and Its Impact on Purchase Decisions. 
Journal of Business Administration (JAB). 24(1): 1-8

17. Hair JF, Black WC, Babin BJ, Anderson RE. 2010. Multivariate Data Analysis: A Global Perspective (7th Edition). New Jersey (US): Pearson Education, Inc.

18. Hanaysha JR. 2017. An examination of the factors affecting the consumer's purchase decision in the Malaysian retail market. PSU Research Review: An International Journal. Emerald Publishing Limited. 2(1): 7-23.

19. Huda N. 2020. The influence of brand image on the decision to purchase a Matic Yamaha scooter in Makassar. Journal of Islamic Financial Institutions, Economics and Business. 2(1): 37-43.

20. Hutauruk R. Martinus. 2020. The application of the 4C marketing mix to consumer purchasing decisions to choose outdoor cafes moderated by consumer behavior in the Covid-19 pandemic situation. Innosa Research Journal. 2(2): 8091.

21. Jalilvand MR, Samiei N. 2012. The effect of electronic word of mouth on brand image and purchase intention. Marketing Intelligence and Planning. 3(4): 460-476.

22. Javadi MHM, Dolatabadi HR, Nourbakhsh M, Poursaeedi A, Asadollahi AR. 2012. An Analysis of Affecting Factors on Online Shopping Behavior of Consumers. International Journal of Marketing Studies. 4(5):81-98.

23. [Kominfo]. Ministry of Communication and Information. 2020. Bappenas Study, Digitalization Makes MSMEs Survive During a Pandemic. [Accessed January 21, 2021]. Taken from: https://kominfo.go.id/content/detail/31544/k ajian-bappenas-digitalisasi-jadikan-umkmbertahan-saat-pandemi/0/berita_satker.

24. Kotler P and Armstrong. 2008. Principles of Marketing. Jakarta (ID): Erlangga.

25. Kotler $\mathrm{P}$ and Keller L. 2012. Marketing Management. 14th Ed. Global Edition. New York (US): Pearson Prentice Hall.

26. Kotler P. 2000. Marketing Management Volume 2. Jakarta (ID): Bumi Aksara.

27. Kurniawan Bagus PY. 2016. Analysis of Marketing Mix Confirmatory Factors for Brand Image Creation of Banana Mas Kirana (Musa acuminate) Lumajang Regency. Journal of Theoretical and Applied Management. 9(2): 97-119.
28. Lauterborn B. 1990. New Marketing Litany: Four Ps Passe: C-Wors Take Over. Advertising Age, 61(41), p. 26.

29. Li J, Xue W, Yang F, and Li Y. 2016. A research review on the effect of EWOM. Wuhan International Conference on eBusiness-WHICEB Proceedings; 2016 May 27; Tianjin, China. Tianjin $(\mathrm{CN})$ : Association for Information System Electronic Library (AISeL).

30. Mican, D and Taut, Watershed. 2018. Analysis of The Factors Impacting the Online Shopping Decision-Making Process. Studia Universitatis Babes-Bolyai Oeconomica. 65(1): 54-66.

31. Nurhasanah, Mahliza F, Nugroho L, Yananto MH. 2017. The effect of EWOM, brand trust, brand ambassador on purchase decision at Tokopedia online Shopping site. International Conference on Advanced Science and Technology. IOP Publishing: 1$7 . \quad$ DOI: $\quad 10.1088 / 1757-$ 899X/1071/1/01/012017

32. Oktariani D, Hubeis Aida Vitayala S, Sukandar D. 2016. Generation $x$ and generation y job satisfaction towards work commitments at Bank Mandiri Palembang. Journal of Business and Management Applications. 3(1): 12-22.

33. Sanjiwani NMD, IGAKG atmosphere. 2019. The role of brand image in mediating the influence of product quality on purchasing decisions. E-Journal of Management 8(11); 6721-6740.

34. Schiffman LG and Kanuk LL. 2008. Consumer Behavior. Translated by: Zoelkifli Kasip. Jakarta (ID): PT. INDEX.

35. Seong K. Min, Kim Ji Hye. 2018. Linking Marketing mix elements to passion-driven behavioral toward a brand. International Journal of Contemporary Hospitality Management. 30(10): 3040-3058.

36. Soni N and Verghese M. 2018. Analyzing The Impact of Online Brand Trust on Sales Promotion and Online Buying Decision. THE IUP Journal of Marketing Management. 17(3): 8-24.

37. Sumarwan U. 2015. Consumer Behavior: Theory and Its Application in Marketing. Bogor (ID): Ghalia Indonesia.

38. Sumarwan U, Hartoyo and Fahmi I. 2018. Business and Consumer Research Methods. Bogor (ID): IPB Press. 
39. Valentine DB, Powers TL. 2013. Generation $\mathrm{Y}$ values and lifestyles segments. Journal of Consumer Marketing. 30(7): 597-606.

40. Venessa I and Arifin Z. 2017. The Influence of Brand Image (Brand Images) and Price on Consumer Purchase Decisions. Journal of Business Administration (JAB). 51(1): 44-48.

41. Yusmarni Y, Putri A, Paloma C. 2020. Marketing performance of Kopi Solok in industrial revolution 4.0: a Case study of Solok Rodjo Cooperative in Solok District.
International Conference of Bio-based Economy and Agricultural Utilization 2019. IOP Publishing Ltd: 1-6. DOI: 10.1088/1755-1315/733/1/012064.

How to cite this article: Reni Kusmiati, M. Syamsul Maarif, Suprehatin. Product purchase decision analysis from Bittersweet by Najla dessert box. International Journal of Research and Review. 2022; 9(1): 423-445. DOI: https:// doi.org/10.52403/ijrr.20220149 